\title{
Didactic possibilities of the use of infographics during the study of the discipline "Ukrainian language (for professional purposes)"
}

\author{
Zminchak N. ${ }^{*}$ \\ Odessa State Academy of Civil Engineering and Architecture, Odessa, Ukraine
}

Received: 10.06 .2020

Accepted: 24.06 .2020

\begin{abstract}
At the present stage of educational technologies development and teaching methods, the innovative teacher's activity is a key area of implementation of the process of education modernization. The challenges facing the scientific community in terms of reforming modern education is the need to develop not only professional skills and abilities, but also the general self-development of the individual, which are increasingly addressed through the introduction of innovative technologies. Such technologies are now available. Innovative education characteristics are creativity, search and use of non-traditional forms of teaching material, the need for systematic acquisition of knowledge, extensive use of clarity. The most important language teacher's task is to direct the student to selfknowledge through the process of using the language, choosing the appropriate forms of its study. However, no educational technology can be considered universal. The organization of the obtaining education process in modern conditions requires the inclusion of various information and communication technologies, a creative approach to the process of their creation and understanding of their advantages and disadvantages. The use of multimedia content is a powerful tool for optimizing the process of learning disciplines. Among the effective teaching aids is the use of educational infographics, which allows to implement the above principles. The benefits of using it become obvious given the large amount of information that must be learned by student. Appropriate use of certain types of infographics, a competent approach at all levels (from design to content) its creation in accordance with the specifics of thematic blocks is an effective tool for processing and mastering the material. The use of innovative technologies stimulates the development of both the student and the teacher, who increases the level of skills in working with ICT and media in the process of educational content creating. The combination of innovative and traditional pedagogical technologies stimulates the transition to a systemic model of learning, allows to organize effective educational activities of professional orientation, to provide the process of education with personal orientation.
\end{abstract}

Key words: digital competence, ICT, didactic teaching aids.

\section{Дидактичні можливості використання інфографріки під час вивчення дисципліни "Українська мова (за професійним спрямуванням)"}

Змінчак Н. М.

\author{
Одеська державна академія будівництва і архітектури, Одеса, Україна
}

\begin{abstract}
Анотація. На сучасному етапі розвитку освітніх технологій і методів викладання інноваційна діяльність викладача $€$ ключовим напрямом реалізації процесу модернізації освіти. Викликами, що стоять перед науковою спільнотою з погляду реформування сучасної освіти, $є$ необхідність формування умінь і навичок не лише фахового спрямування, а й загального саморозвитку особистості, які все частіше вирішуються шляхом впровадження інноваційних технологій. Такі засоби нині $€$ на часі. Інноваційна освіта характеризується креативністю, пошуком і використанням нетрадиційних форм викладення матеріалу, необхідністю системного засвоєння знань, широким використанням наочності. Найважливіше завдання викладача мови - спрямувати студента на самопізнання через процес використання мови, дібравши відповідні форми її вивчення. Проте жодна освітня технологія не може розглядатися як універсальна. Організація процесу здобуття освіти в сучасних умовах вимагає включення різних інформаційно-комунікаційних технологій, творчого підходу до процесу їх створення й розуміння їхніх переваг і недоліків. Використання мультимедійного контенту слугує потужним інструментом оптимізації процесу вивчення навчальних дисциплін. Серед дієвих засобів навчання бачиться використання освітньої інфографріки, що дає змогу реалізувати вищенаведені принципи. Переваги її використання стають очевидними з огляду на значні обсяги інформації, що їх повинен засвоїти студент.
\end{abstract}

Corresponding Author: Zminchak Natalia Mykhailivna, Tel. 0667458314. E-mail: natalia.zminchak@ukr.net Odessa State Academy of Civil Engineering and Architecture, Didrikhson st., 4, Odessa, 65000.

Biдnовідальний автор: Змінчак Наталія Михайлівна, Тел. 0667458314. E-mail: natalia.zminchak@ukr.net Одеська державна академія будівництва та архітектури, вул. Дідріхсона, 4, Одеса, 65000. 
Доречне використання тих чи інших видів інфографік, грамотний підхід на всіх рівнях (від дизайну до змістового наповнення) її створення відповідно до специфіки тематичних блоків $є$ ефективним інструментом обробки й засвоєння матеріалу. Використання інноваційних технологій стимулює розвиток і студента, і викладача, який у процесі створення навчального контенту підвищує рівень володіння навичками роботи з IКT та медіа. Поєднання інноваційних і традиційних педагогічних технологій стимулює перехід до системної моделі навчання, дає змогу організувати ефективну навчальну діяльність фахового спрямування, надати процесу здобуття освіти особистісної орієнтації.

Ключові слова: цифрова компетентність, IKT, дидактичні засоби навчання.

\title{
Дидактические возможности использования инфографики при изучении дисциплины "Украинский язык (по профессиональному направлению)"
}

\author{
Зминчак Н. М.
}

\author{
Одесская государственная академия строительства и архитектуры, Одесса, Украина
}

\begin{abstract}
Аннотация. На современном этапе развития образовательных технологий и методов преподавания инновационная деятельность преподавателя является ключевым направлением реализации процесса модернизации образования. Вызовами, стоящими перед научным сообществом с точки зрения реформирования современного образования, является необходимость фрормирования умениям и навыкам не только профессионального направления, но и общего саморазвития личности, которые все чаще решаются путем внедрения инновационных технологий. Такие средства сейчас крайне актуальны. Инновационное образование характеризуется креативностью, поиском и использованием нетрадиционных форм изложения материала, необходимостью системного усвоения знаний, широким использованием наглядности. Важнейшая задача преподавателя языка направить студента на самопознание через процесс использования языка, подобрав соответствующие формы его изучения. Однако ни одна образовательная технология не может рассматриваться как универсальная. Организация процесса получения образования в современных условиях требует включения различных информационно-коммуникационных технологий, творческого подхода к процессу их создания и понимания их преимуществ и недостатков. Использование мультимедийного контента служит мощным инструментом оптимизации процесса изучения учебных дисциплин. Среди действенных средств обучения видится использование образовательной инфографики, что позволяет реализовать вышеприведенные принципы. Преимущества ее использования становятся очевидными учитывая значительные объемы информации, которые должен усвоить студент. Уместное использование тех или иных видов инфографик, грамотный подход на всех уровнях (от дизайна до содержательного наполнения) ее создания в соответствии со спецификой тематических блоков является эффективным инструментом обработки и усвоения материала. Использование инновационных технологий стимулирует развитие и студента, и преподавателя, который в процессе создания учебного контента повышает уровень владения навыками работы с ИКТ и медиа. Сочетание инновационных и традиционных педагогических технологий стимулирует переход к системной модели обучения, позволяет организовать эфффективную учебную деятельность профессионального направления, придать процессу получения образования личностной ориентации.
\end{abstract}

Ключевые слова: цифровая компетентность, ИКТ, дидактические средства обучения.

\section{Bcmyn}

Потужний розвиток інформаційних технологій наразі змінює обличчя освіти, починаючи від електронних підручників і закінчуючи інтерактивними курсами. Застосування онлайн ресурсів розширює перелік методів викладання (змішане навчання (blended learning), мікронавчання, масові відкриті онлайн курси (МВОК) та гейміффікація навчального процесу) й сприяє оптимізації традиційних форм навчання.

Однією 3 найвпливовіших інновацій у сфері вищої стала поява МВОК, що все більше актуалізуються в умовах, що склалися у 2020 році. Крім того, сучасні студенти надають перевагу отриманню інформації за допомогою мережі Інтернет, що дозволяє оптимізувати використання часу в процесі навчання і сприяє мобільності. Наразі стає зрозумілою невідворотність змін, що їх зазнає освіта.

На законодавчому рівні основні засади організації та запровадження дистанційного навчання визначаються «Положенням про дистанційне навчання», що постулює необхідність використання вебресурсів, їх змістовне, методичне та дидактичне наповнення [12].

Meта роботи: демонстрація використання засобу інфографіки у процесі створення навчального контенту на прикладі дисципліни “Українська мова (за професійним спрямуванням)". 


\section{II Матеріал і методи дослідження}

У ході дослідження проведено аналіз вітчизняних і зарубіжних публікацій, що в них розглянуто предмет аналізу. В Україні специфіку дистанційного навчання і онлайн технологій в освіті досліджують Л. Білоусова, В. Биков, Н. Житеньова, М. Кухаренко, Г. Міщенко, Л. Панченко, Н. Сиротенко, С. Силкіна та інші.

Ведучи розмову про онлайн освіту, перш за все, маємо на увазі МВОК, що визначаються як набір безкоштовних лекцій, тестів та платформ для обговорення лекційного матеріалу. Міжнародні освітні платформи (Coursera, edX.org, Khan Academy тощо), а також українські (EdEra, Prometheus, ВУМ тощо) містять безкоштовні курси, скомпоновані за університетськими програмами, що $\epsilon$ доступними для будь-якого слухача.

Доступність, індивідуалізація, інтернаціоналізація освіти, оперативність є перевагами МВОК. Силкіна С. вважає, що саме "фінансова доступність МВОК для слухачів курсів є запорукою їх масовості та популярності» $[13,121]$. Наголошуючи на перевагах онлайн освіти, дослідниця подає й аналіз недоліків, серед яких неможливість через технічні причини запропонувати вільний доступ до освіти усім охочим незалежно від країни проживання, соціальних умов тощо. Не на користь онлайн освіти свідчить і той факт, що завершує курси лише десята частина слухачів, яким вистачає мотивації та самодисципліни.

Щодо мотивації студента, то це, на жаль, проблема не лише онлайн освіти, а освіти загалом. Цей феномен докладно досліджено у статті Г. Гутнера "Наукові і утилітарні задачі. До питання про мотивацію при вивченні наук". Вчений вбачає причину відсутності мотивації до вивчення наук у такій їі специфріці: мотивація до вирішення практичної задачі виникає природним шляхом, тоді як наукова задача потребує інтересу до об'єкта вивчення безвідносно до його утилітарної цінності» [Див. 6, 28]. Відтак вчений доходить висновку про непродуктивність доказів практичної користі наукових задач, адже таким чином вони перестають бути науковими, нівелюється зусилля духу, прикладені для наближення до істини [Див. 6, 45].

Залучення різних каналів сприйняття, використання діджитал технологій, модернізація засобів навчання видаються тими чинниками, що допоможуть вплинути на ситуацію, що склалася.

Разом з цим онлайн освіта вимагає ретельнішого підходу до розробки навчальних матеріалів, особливу роль відіграє оптимальний вибір дидактичних засобів, які використовуються в освітньому процесі в якості носіїв навчальної інформації, та веб-технологій. За визначенням Кільченко А.: «Вебтехнологія - це сукупність методів та програмно-технічних засобів, інтегрованих з метою ефективного опрацювання веб-ресурсів, які знаходяться у веб-просторі» $[7,4]$.

Відповідно складені онлайн курси можуть забезпечити не лише ознайомлення з основною програмою, а й поглиблене вивчення дисципліни успішними студентами.

3 розвитком онлайн освіти удосконалюються й цифрові технології. Засоби IКT, що їх використовують в системі освіти, "включають:

- технічні засоби (комп'ютери, комп'ютерні комплекси, мультимедійні проєктори, сенсорні дошки, апаратні гаджети: графрічні планшети, смартфони тощо);

- програмні засоби (системні, загального призначення, прикладне програмне забезпечення, у тому числі навчального призначення);

- засоби для під'єднання до Інтернету та забезпечення повноцінної можливості роботи в ньому (сервери, лінії зв'язку, модеми, програми пошуку різноманітних даних в Інтернет тощо);

- спеціально створене для системи освіти інформаційне наповнення (контент) в Інтернеті;

- методичне забезпечення стосовно використання засобів інформаційно-комунікаційних технологій» $[5,59]$.

Ефективним видається застосування такого способу викладу навчального контенту як інфрографіка (з англ. - information graphics). Інфрографіку визначають як передавання великого обсягу інформації за допомогою короткого тексту й візуальних елементів, структурованих певним чином [19]. Саме структура відрізняє їі від візуалізації: якщо в інфографіці інформацію викладено, щоб направити сприймача на конкретні висновки, то візуалізація дозволяє робити власні, засновуючись на викладених у ній фрактах. 
у навчальному процесі інфографріка виконує такі ффункції: "презентаційна, інформаційна, пояснювальна, переконувальна, реконструювальна, прогнозувальна, організаційна, фасилітативна В основі застосування інфографіки лежать принципи лаконічності, креативності, візуалізації інформації, організованості, прозорості, актуальності, простоти" [11, 123]. Використання освітньої інфогррафіки реалізує можливості медіадидактики за принципами наочності, доступності, емоційності, що сприяє ефективному засвоєнню навчального матеріалу.

\section{III Результати}

Уявлення про переваги використання інфограффіки сприяє розумінню алгоритму її створення. Серед аргументів на користь використання інфографіки вчені першорядним називають візуальний тип сприйняття інформації [11]. Проте такі висновки нині піддаються критиці: учені доводять непродуктивність поділу на типи за фрормою сприйняття інформації, називаючи це нейроміфром. Дослідники доходять висновку, що йдеться не про результативне засвоєння інформації, а скоріше уподобання студента щодо обробки певних типів інформації [20]. Тому пропонується не витрачати час на створення методик навчання, що орієнтуються на непідтверджену теорію.

Використання інфографріки у навчанні дає змогу не просто включити візуальний канал сприйняття, а задіює таку особливість психіки, як системність. Адже нині спостерігається перенасиченість інформацією, а інфографіка задовольняє потребу в представленні комплексної концепції у стислому вигляді. Студент бачить цілісну картину, яку зможе поглибити, шукаючи додаткову інформацію самостійно. Таким чином інфографіка тримає увагу й викликає зацікавлення у студента.

У продовження цієї думки, варто сказати про сторітелінг, як важливий інструмент інфографіки. Від візуалізації вона відрізняється саме наявністю цього компонента, вона розповідає історію, репрезентує точку зору суб'єкта мовлення у завершеному вигляді. А тому змістове наповнення інфографіки має бути достовірним і ясним, не повинно містити суб'єктивної інформації та припущень.

М. Фарухшина до основних функцій сторітелінгу в освітньому процесі відносить:

- пропагандистську (як інструмент переконання, що дозволяє надихнути або мотивувати);

- об'єднувальну (історії є інструментом розвитку колективної культури, спільної ідентичності спільноти);

- комунікативну (підвищує ефективність спілкування на різних рівнях);

- мотивуючу (розширює арсенал засобів мотивації);

- утилітарну (у низці випадків це найпростіший спосіб донести до інших зміст завдання або проекту) [Див. 15].

Мотивуюча функція видається найбільш проявленою в інфограффіці.

Ще однією характеристикою інфографіки є мультимедійність. Обираючи медіа для наповнення інфограффіки, слід мати на увазі те, що надто строкатий візуал відволікатиме студента від сприйняття тексту. Зображення, що використовуються, мають бути доречними, повинні підкреслювати інформацію й сприяти її легкому відтворенню. Серед візуальних елементів інфографіки вирізняють зображення, діаграми, піктограми, концептуальні мапи тощо. Динамічна інфографріка, крім візуальних елементів, може містити звуковий супровід. Сучасний викладач має змогу обирати серед значної кількості онлайн ресурсів, призначених для створення візуальних матеріалів, зокрема й інфографік. Серед них Canva, Inkscape, Adobe Illustrator, Piktochart, Gapminder, Tableau, Wordle, Visual.ly, ResumUp, Easel.ly тощо.

Нижче наведено приклади інфограффік з електронних ресурсів (рис. 1, 2, 3). Серед різновидів інфографік виокремлюють такі: статистична інфограффіка, інформаційна інфографріка, географічна інфографіка, порівняльна інфографріка тощо. Використання того чи іншого різновиду диктується типом інформації, що її повинен засвоїти студент. Наведені інфографріки репрезентують порівняльний (рис.1) та інформаційний (рис. 2) ії типи. Велику кількість якісних інфографрік, зокрема лінгвістичних, розміщують на своїх інтернет-сторінках газета «День» (рис. 3) та агентство «Укрінформ». Наведена нижче інфограффіка є прикладом трансформації розгалуженого навчального матеріалу у простій формі, що дозволяє охопити великий пласт інформації у систематизованому вигляді.

Залучення інфограффіки у процесі навчання дає змогу реалізувати принципи наочності, креативності, системності. 


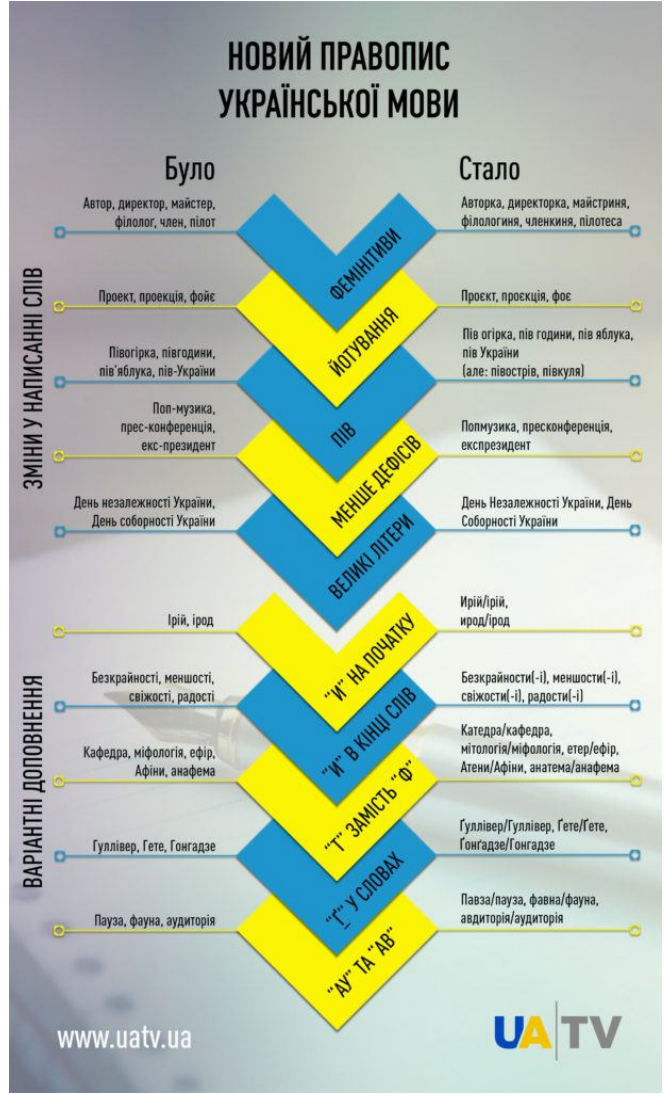

Рис. 1. Інфографіка з сайту uatv.uа

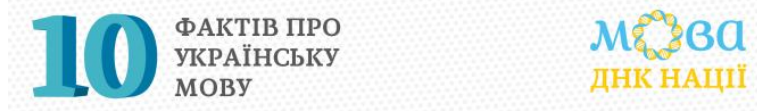
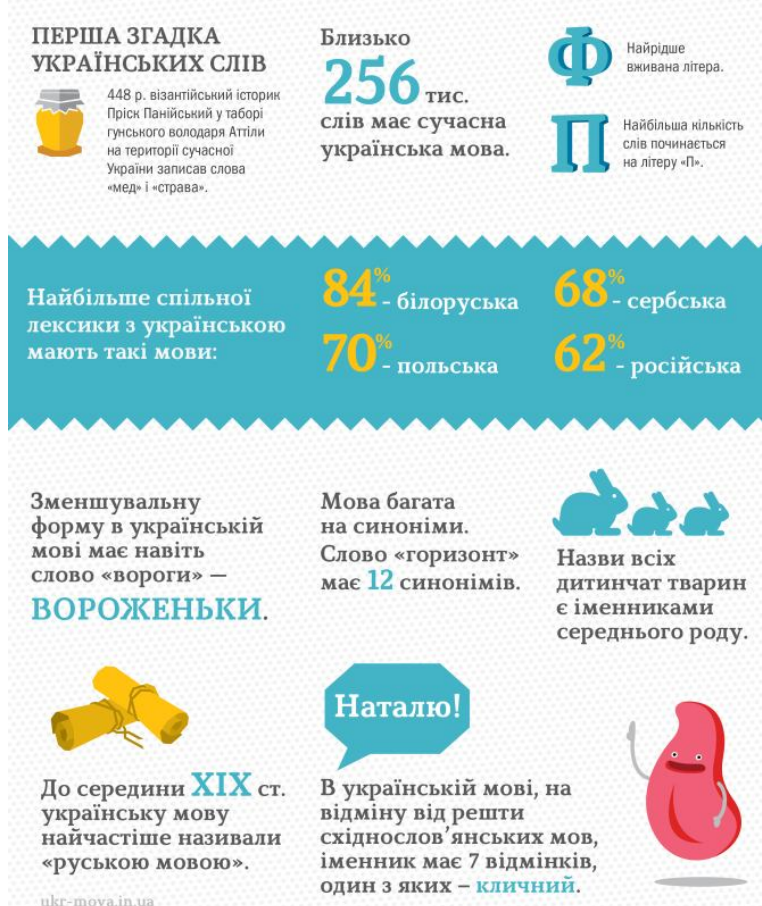

Рис. 2. Інфографріка освітнього проєкту «Мова ДНК нації»

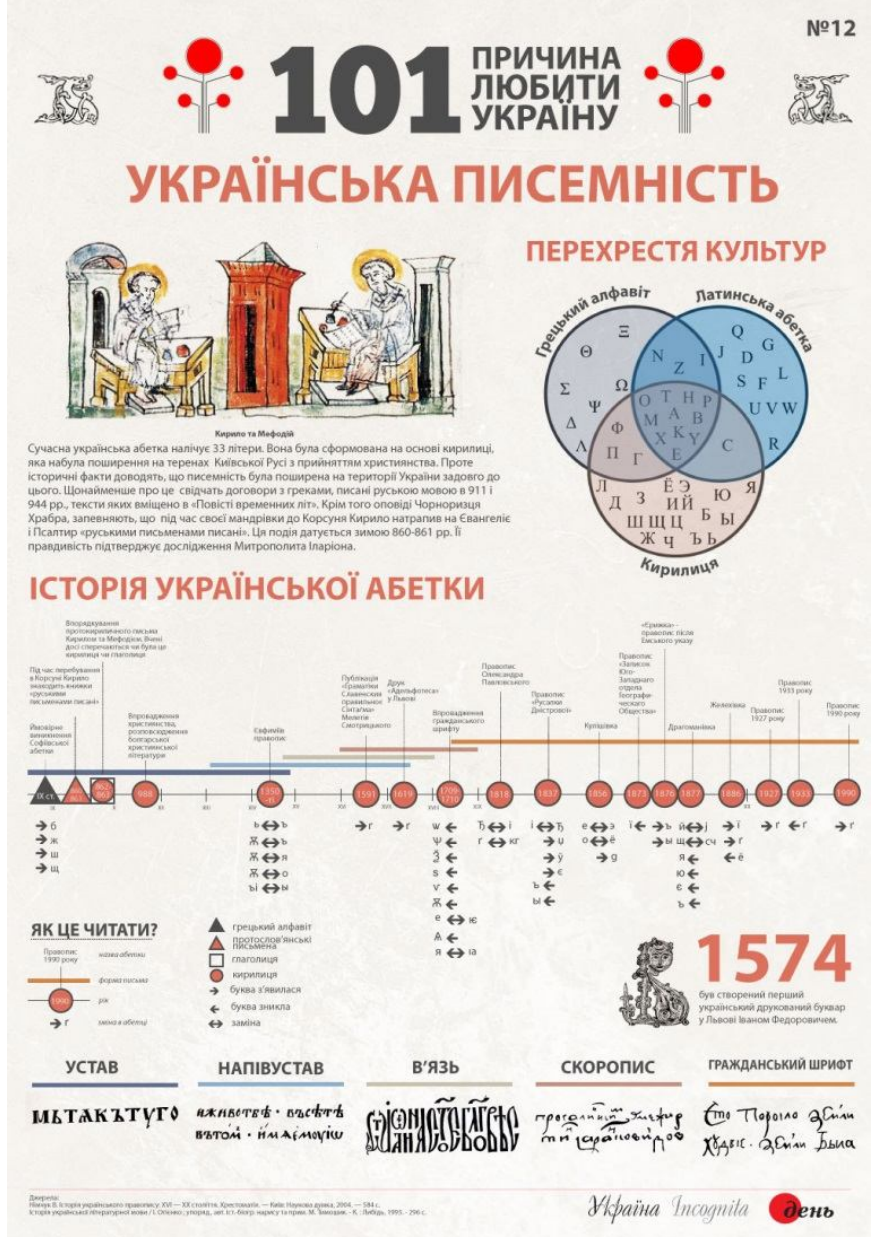

Рис. 3. Інфографріка до Дня української писемності газети “День" 


\section{IV Обговорення}

Над обґрунтуванням методологічних засад розвитку методів викладання під час дистанційного навчання працює велика кількість вітчизняних науковців, зокрема: Бублик В. [3], Вишнівський В. [10], Козубовська І. [8] та ін. Питання ж використання інфограффіки в українських ЗВО потребує поглиблених наукових досліджень, які вже розпочали своїми науковими розвідками Білоусова Л. [1, 2], Вовк О. [4], Панченко Л. [11]. На міжнародному рівні аналіз використання інфографріки в освіті межує 3 використанням її під час вивчення дисциплін медичного фаху [16, 18, 19].

Практичне використання інфографріки у процесі вивчення дисципліни «Українська мова (за професійним спрямуванням)» показало її ефективність, тому методичні матеріали кафедри українознавства поповнюються ріними видами інфограффік.

\section{EКОНОМIUHА ТЕРМІНОЛОГІЯ}

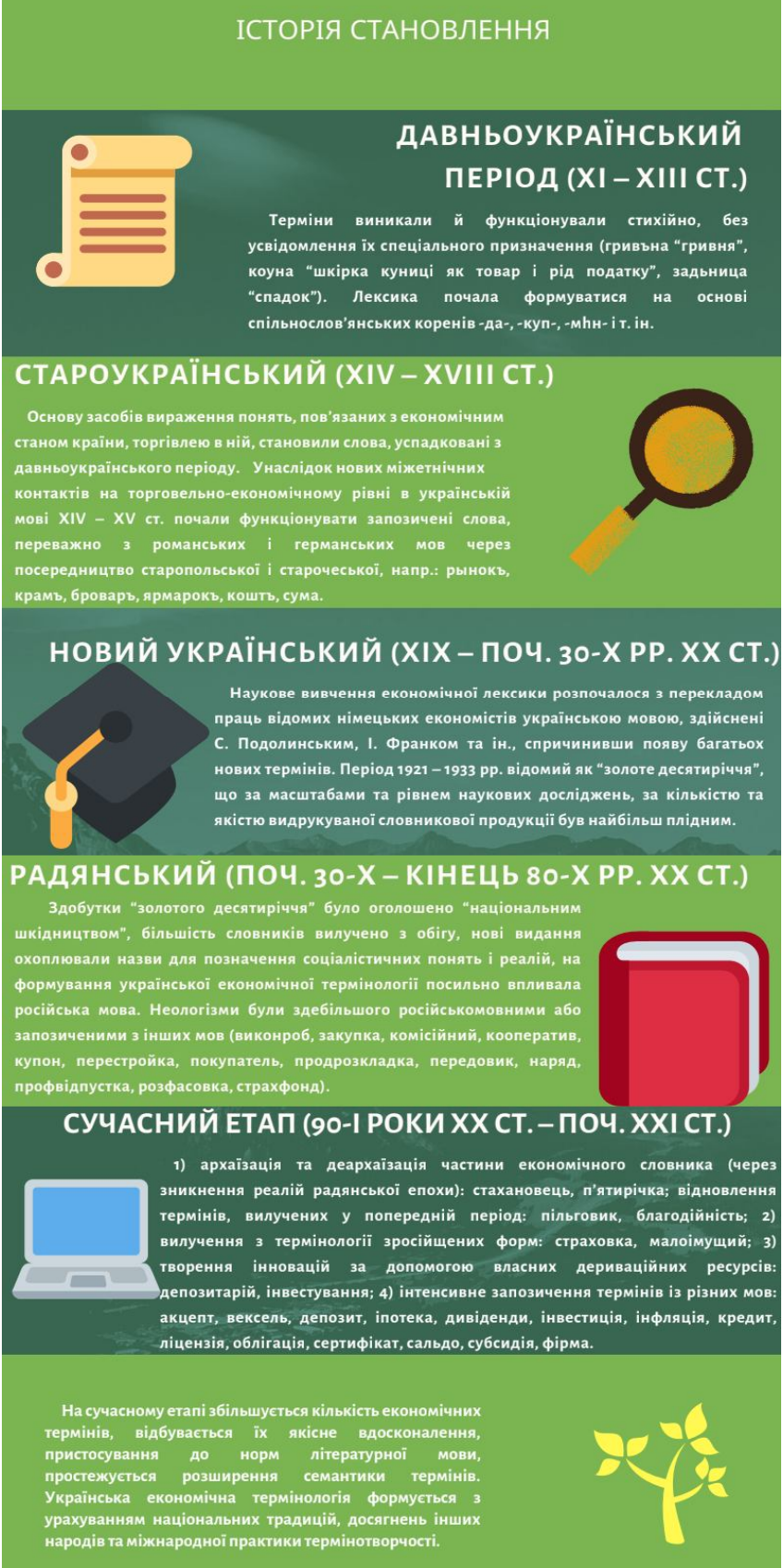

Рис. 4. Інфограффіка, створена на платформі Canva 
Дистанційне навчання спонукає до впровадження інтерактивних технологій викладання матеріалу, що актуалізує впровадження новітніх педагогічних розробок у сфері IКТ. А це у свою чергу стимулює науково-педагогічних працівників до розширення свої компетенцій у використанні засобів еlearning. Проте створення справді якісної інфографріки вимагає компетенцій графрічного дизайнера, який працюватиме над сукупністю графічних елементів, стилю типографіки й вдалим поєднанням кольорів. Тому створення освітніх інфограсфік бачиться процесом фаховим, однак це не виключає можливості самостійного створення таких матеріалів.

Важливо відзначити те, що інфографіка може не лише концентрувати увагу студента, а й активізувати його здібності засвоєння матеріалу. Комбінація змістового компонента й медіа у певному порядку змусять суб'єкта навчання зосередитися на головному, він матиме змогу ментально відтворити цілісну картину наукової теми, встановити логічні зв'язки, виокремити потрібний шар інформації. Підвищити її ефективність може накладення аудіо- та відеоматеріалів (інтерактивна інфографріка), що зацікавить студента і залучить різні види сприйняття інформації одночасно.

Отже, інтерактивну інфографріку характеризують здатність містити значний обсяг інформації, сучасна форма, активна взаємодія зі здобувачем освіти, що значно збільшує їі ефективність.

\section{V Висновки}

Використання інфографіки в ЗВО є одним зі шляхів забезпечення попиту сучасних студентів на діджиталізацію освітнього процесу. Освітня інфографіка представляє навчальні матеріали, розбиті за темами, які можуть використовуватися в курсах під час дистанційного або змішаного навчання. Серед викликів, з якими зіштовхнулись викладачі під час використання цієї технології, $€$ необхідність підвищення рівня володіння IКТ, велика кількість часу та зусиль.

До переваг використання інфографріки належать високий рівень вдоволеності студентів щодо такої фрорми подання матеріалу. Інфографріка є перспективним засобом для забезпечення дистанційної складової навчання, як і очної, сприяє систематизації та узагальненню навчальної інформації чи наукових понять.

Отже, освітня інфографіка $€$ ефрективною формою викладу навчального матеріалу. У процесі її створення використовуються сучасні середовища комп'ютерних інформаційних технологій. Вона дозволяє сконцентрувати й ущільнити значні обсяги розрізненої навчальної інформації, за допомогою співдії інформаційних блоків дає можливість акцентувати зв'язки між частинами осітнього матеріалу, значно підвищуючи ефективність сприйняття інформації.

Питання про застосування інфографіки у процесі вивчення дисципліни «Українська мова (за професійним спрямуванням)», порушене у публікації, потребує поглибленого аналізу. Подальші наукові розробки можуть бути спрямовані на ефективність використання інфографіки у різних вікових чи гендерних групах; доцільність використання різних видів інфографрік на етапі вивчення нового матеріалу чи систематизації отриманих знань.

\section{Бібліографрічні посилання}

1. Белоусова Л., Житенева Н. Дидактические аспекты использования технологий визуализации в учебном процессе общеобразовательной школы. Інформаційні технології й засоби навчання: електрон. наук. фахове вид. 2010. Т. 16, № 2. URL: http://journal.iitta.gov.ua/index.php/itlt/article/view/1017.

2. Білоусова Л., Житєньова Н. Функціональний підхід до використання технологій візуалізації для інтенсифікації навчального процесу. Інформаційні технології й засоби навчання: електрон. наук. фахове вид. 2017. T. 57, No 1. URL: https://journal.iitta.gov.ua/index.php/itt/article/view/1525/1132.

3. Бублик В. Шляхами дистанційної освіти та електронного навчання. Наукові записки НаУКМА. Комп'ютерні науки. 2018. T. 1. C. 4-9.

4. Вовк О. Інфографріка як ефективний засіб навчання. Системи обробки інформації. 2017. Вип. 4. С. $199-205$

5. Засоби інформаційно-комунікаційних технологій єдиного інформаційного простору системи освіти України : монографрія / [В. В. Лапінський, А. Ю. Пилипчук, М. П. Шишкіна та ін.]; за наук. ред. проф. В. Ю. Бикова. Київ: Педагогічна думка, 2010. $160 \mathrm{c}$.

6. Гутнер Г. Наукові і утилітарні задачі. До питання про мотивацію при вивченні наук. Філософрія освіти. 2016 . № 2 (19). С. $27-47$.

7. Кільченко А., Поповський О., Тебенко О., Матросова Н. Базові поняття і терміни веб-технологій. Київ, Україна: ॥ТЗН НАПН України, 2014. 
8. Козубовська І., Сагарда В., Пічкар О. Дистанційне навчання в системі освіти : навч. посіб. 2-ге вид., перероб., доповн. Ужгород : [б. в.], 2002. 361 c.

9. Овсяннікова В. Дистанційне навчання в освітньому процесі вищого навчального закладу. Вісник Запорізького національного університету. Педагогічні науки. 2016. № 2. C. 56-60. URL: http://nbuv.gov.ua/UJRN/Vznu_ped_2016_2_10

10. Організація дистанційного навчання. Створення електронних навчальних курсів та електронних тестів : навч. посіб. I Вишнівський В., Гніденко М., Гайдур Г., Ільїн О. Київ : ДУТ, 2014. 140 с.

11. Панченко Л., Разорьонова М. Використання інфограффіки в освіті. Наукові записки [Кіровоградського державного педагогічного університету імені Володимира Винниченка]. Серія: Проблеми методики фізико-математичної і технологічної освіти. 2016. Вип. 10(2). С. 122-126.

12. Про затвердження Положення про дистанційне навчання : наказ Міністерства освіти і науки України від 25 квітня 2013 p. № 466. URL: https://zakon.rada.gov.ua/laws/show/z0703-13

13. Силкіна С. Он-лайн освіта як нова практика гуманізму. Філософія освіти. 2016. № 1 (18). С. 117-124.

14. Терлецька Т. Аналіз використання масових відкритих онлайн курсів в освітньому процесі університету на прикладі спеціальності «Дошкільна освіта». Електронне наукове фахове видання "ВІДКРИТЕ ОСВІТНЄ Е-СЕРЕДОВИЩЕ СУЧАСНОГО УНІВЕРСИТЕТУ". 2020. № 8. С. 136-146.

15. Фарухшина М.Ш. Педагогічний маркетинг у професійній діяльності педагога Нової української школи. Просресійний розвиток педагога Нової української школи в умовах формальної і неформальної освіти: електронний збірник спецкурсів: авторський колектив. загальна ред. проф. Т. М. Сорочан. К.: ЦІППО, 2018. 300 с.

16. Joni $\mathrm{C}$. Carroll. Using prescription dispensing data infographics to facilitate collaborative pharmacist-prescriber discussions on mutual patients // Journal of the American Pharmacists AssociationVolume 59, Issue 2, March-April 2019. Pages 232-237.

17. Lankow J. Infographics: The Power of Visual Storytelling. Wiley, 2012. $264 \mathrm{p}$.

18. Ozdamli F. Statistical reasoning of impact of infographics on education. Procedia Computer Science 2016. Vol. 102. pp. 370 377.

19. Smiciklas M. The Power of Infographics: Using Pictures to Communicate and Connect with Your Audience. Indianapolis: Quebec Publishers. 2012.

20. Willingham, Daniel T., Hughes, Elizabeth M., \& Dobolyi, David G. The Scientific Status of Learning Styles Theories. Teaching of Psychology, 2015. 42(3). pp. 266-271.

\section{References}

1. Belousova L. Zhyteneva N. (2010). Dydaktycheskye aspekty yspolzovanyia tekhnolohyi vyzualyzatsyy $v$ uchebnom protsesse obshcheobrazovatelnoi shkoly. Informatsiini tekhnolohii y zasoby navchannia. Elektron. nauk. fakhove vyd. T. 16 No 2. URL: http://journal.iitta.gov.ua/index.php/itt/article/view/1017.

2. Bilousova L. Zhytienova N. (2017). Funktsionalnyi pidkhid do vykorystannia tekhnolohii vizualizatsii dlia intensyfikatsii navchalnoho protsesu. Informatsiini tekhnolohii y zasoby navchannia. Elektron. nauk. fakhove vyd. T. 57 No 1. URL: https://journal.iitta.gov.ua/index.php/itt/article/view/1525/1132.

3. Boublik, V. (2018). On road to distance education and e-learning. NaUKMA Research Papers. Computer Science, 1, 4-9. https://doi.org/10.18523/2617-3808.2018.4-9

4. Vovk O. (2017). Infohrafika yak efektyvnyi zasib navchannia. Systemy obrobky informatsii. Vyp. 4.

5. Lapinskyi V. (2010). Zasoby informatsiino-komunikatsinykh tekhnolohii yedynoho informatsinoho prostoru systemy osvity ukrainy: monohrafiia. Kyiv: Pedahohichna dumka.

6. Hutner H. (2016). Naukovi i utylitarni zadachi. Do pytannia pro motyvatsiiu pry vyvchenni nauk. Filosofiia osvity. 2016. No. 2 (19).

7. Kilchenko A. (2014). Bazovi poniattia i terminy veb-tekhnolohii. Kyiv, Ukraina: IITZN NAPN Ukrainy.

8. Kozubovska I. (2002). Dystantsiine navchannia v systemi osvity : navch. posib. 2-he vyd., pererob., dopovn. Uzhhorod : [b. v.].

9. Ovsiannikova V. (2016). Dystantsiine navchannia v osvitnomu protsesi vyshchoho navchalnoho zakladu. Visnyk Zaporizkoho natsionalnoho universytetu. Pedahohichni nauky. No. 2. URL: http://nbuv.gov.ua/UJRN/Vznu_ped_2016_2_10

10. Vyshnivskyi V. (2014). Orhanizatsiia dystantsiinoho navchannia. Stvorennia elektronnykh navchalnykh kursiv ta elektronnykh testiv : navch. posib. Kyiv : DUT.

11. Panchenko L. (2016). Vykorystannia infohrafiky v osviti. Naukovi zapysky [Kirovohradskoho derzhavnoho pedahohichnoho universytetu imeni Volodymyra Vynnychenka]. Seriia: Problemy metodyky fizyko-matematychnoi i tekhnolohichnoi osvity. Vyp. 10(2).

12. Pro zatverdzhennia Polozhennia pro dystantsiine navchannia : nakaz Ministerstva osvity i nauky Ukrainy vid 25 kvitnia 2013 r. No. 466. URL: https://zakon.rada.gov.ua/laws/show/z0703-13

13. Sylkina S. (2016). On-lain osvita yak nova praktyka humanizmu. Filosofiia osvity. No. 1 (18).

14. Terletska T. (2020). Analiz vykorystannia masovykh vidkrytykh onlain kursiv $\mathrm{v}$ osvitnomu protsesi universytetu na prykladi spetsialnosti «Doshkilna osvita». Elektronne naukove fakhove vydannia "VIDKRYTE OSVITNle E-SEREDOVYShchE SUChASNOHO UNIVERSYTETU". No. 8. 
15. Farukhshyna M.Sh. (2018). Pedahohichnyi marketynh u profesiinii diialnosti pedahoha Novoi ukrainskoi shkoly. Profesiinyi rozvytok pedahoha Novoi ukrainskoi shkoly v umovakh formalnoi i neformalnoi osvity: elektronnyi zbirnyk spetskursiv: avtorskyi kolektyv. zahalna red. prof. T. M. Sorochan. K.: TsIPPO.

16. Joni C. (2019). Carroll. Using prescription dispensing data infographics to facilitate collaborative pharmacist-prescriber discussions on mutual patients // Journal of the American Pharmacists AssociationVolume 59, Issue 2.

17. Lankow J. (2012). Infographics: The Power of Visual Storytelling. Wiley. $264 \mathrm{p.}$

18. Ozdamli F. (2016). Statistical reasoning of impact of infographics on education. Procedia Computer Science. Vol. 102.

19. Smiciklas M. (2012). The Power of Infographics: Using Pictures to Communicate and Connect with Your Audience. Indianapolis: Quebec Publishers.

20. Willingham, Daniel T., Hughes, Elizabeth M., \& Dobolyi, David G. (2015). The Scientific Status of Learning Styles Theories. Teaching of Psychology. 42(3).

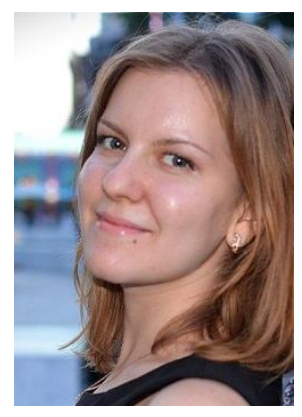

Змінчак Наталія Михайлівна,

старший викладач,

Одеська державна академія будівництва та архітектури,

вул. Дідріхсона, 4, Одеса, 65000

Тел. 0667458314. E-mail: natalia.zminchak@ukr.net

Zminchak Natalia Mykhailivna,

Senior Teacher,

Odessa State Academy of Civil Engineering and Architecture,

Didrikhson st., 4, Odessa, 65000

Tel. 0667458314. E-mail: natalia.zminchak@ukr.net

ORCID: 0000-0003-2871-1157

\section{Citation (APA):}

Zminchak, N. (2020). Didactic possibilities of the use of infographics during the study of the discipline "Ukrainian language (for professional purposes)". Engineering and Educational Technologies, 8 (2), 69-77. doi: https://doi.org/10.30929/2307-

9770.2020 .08 .02 .06

\section{Цитування (ДСТУ 8302:2015):}

Змінчак Н. М. Дидактичні можливості використання інфографіки під час вивчення дисципліни "Українська мова (за професійним спрямуванням)" / Інженерні та освітні технології. 2020. Т. 8. № 2. С. 69-77. doi: https://doi.org/10.30929/23079770.2020 .08 .02 .06

Обсяг статmі: $\quad$ сторінок - 9 ; умовних друк. аркушів - 1,304. 